\title{
KEKUATAN AKTA NOTARIS DALAM MENJAMIN HAK KEPERDATAAN*
}

\author{
RAHMAWATI BOTY \\ STIH Putri Maharaja Payakumbuh \\ Jln. Pahlawan No. 59 Kota Payakumbuh Sumatra Barat \\ e-mail: rahmawati.boty67@gmail.com
}

\begin{abstract}
Notarial Deed is be able guarantee the civil rights of the legal subject, after authentic agreement and determination, so that there is no approval of the cancellation of the parties, the right of civilization of the legal subject can not be contested. The type of research conducted is a Normative Juridical legal research which is about what becomes the Strength of Notarial Deed in guaranted the Right of civilization. This research have The role and function of the Notary deed to the legal relationship between legal subjects is to formalizd the contents. The legal power of notarial deed if used as a means of verification in civil cases is as perfect or formal evidence. Losses in the responsibility of a notary when doing negligence to the client. Notary's role in making deed either in legal theory or practice is Notary also assigned to do registration and validated the letters / deeds made under the hand.
\end{abstract}

Keywords: Notarial Deed, Civil Rights

\begin{abstract}
Abstrak
Akta Notaris mampu menjamin hak keperdataan subjek hukum, setelah dilakukan perjanjian dan ketetapan secara otentik, sehingga belum ada persetujuan pembatalan dari pihak-pihak yang berhak, maka hak keperdataan subjek hukum tersebut tidak dapat diganggu gugat. Jenis penelitian yang dilakukan adalah penelitian hukum Yuridis Empiris yang bersifat tentang apa yang menjadi Kekuatan Akta Notaris dalam menjamin Hak keperdataan. Penelitian ini mengahasilakan yaitu Peranan dan fungsi akta Notaris terhadap hubungan hukum antar subjek hukum adalah untuk mensyahkan secara formal isi. Kekuatan hukum akta Notaris apabila dipergunakan sebagai alat pembuktian dalam perkara perdata adalah sebagai bukti yang sempurna ataupun formal. Kerugian di tanggung notaris apabila melakukan kelalaian terhadap klien. Peranan Notaris dalam pembuatan akta baik di dalam teori hukum maupun praktek adalah Notaris juga ditugaskan untuk melakukan pendaftaran dan mensyahkan surat-surat/akta-akta yang dibuat di bawah tangan.
\end{abstract}

Kata Kunci: Akta Notaris, Hak Keperdataan

\footnotetext{
* Naskah diterima: 31 Agustus 2017, direvisi: 07 Sebtember 2017, disetujui untuk terbit: 13 Sebtember 2017
} 


\section{PENDAHULUAN}

Dalam lalu lintas perhubungan hukum secara perdata antara manusia ataupun badan hukum sering dilakukan perjanjian, keputusan dan ketetapan tertentu yang dituangkan ke dalam suatu akte otentik yang dibuat dan disaksikan dihadapan notaris. Tentunya apabila suatu perjanjian atau ketetapan yang terdapat dalam suatu akte tertentu yang maksudnya agar pihak-pihak yang tertera dalam akta tersebut memiliki hak dan kewajiban secara hukum, sehingga denga demikian isi dari akte tersebut menjadi sah dan harus dipatuhi oleh para pihak.

Setelah isi perjanjian yang diajukan oleh pihak-pihak tertuang dalam akta notaris, maka surat tersebut menjadi surat otentik yang memimiliki kekuatan pembuktian sempurna dalam suatu perkara dan menjadi undang-undang bagi para pihak. Atas dasar kewenangan yang diberikan oleh Undang-Undang kepada notaris, maka Notaris dapat menjamin dan menyimpan akte yang dibuat tersebut juga terdapat aneka ragam pembuktiannya, misalnya kekuatan dalam pembuktian bahwa seseorang telah atau melakukan perbuatan hukum (misal: wasiat, hibah dan sebagainya), kekuatan eksekusi (misal: akte hipotek) memiliki kekuatan lainnya dalam rangka konteks hukum.

Akta Notaris mampu menjamin hak keperdataan subjek hukum, setelah dilakukan perjanjian dan ketetapan secara otentik, sehingga belum ada persetujuan pembatalan dari pihak-pihak yang berhak, maka hak keperdataan subjek hukum tersebut tidak dapat diganggu gugat.
Misalnya hak subjek hukum terdapat dalam akta Notaris tersebut adalah menerima cicilan pembayaran setiap tanggal satu dalam sebulan, atau berhak atas sebidang tanah dari bagian harta tertentu dalam waktu yang telah ditentukan. Berdasarkan adanya akta Notaris yang menuangkan hak-hak tersebut, maka hak perdata subjek hukum tersebut harus dihormati.

Adapun yang menjadi permasalahan dalam bahasan dalam tulisan ini adalah: Bagaimanakah Kekuatan Akta Notaris dalam menjamin Hak keperdataan.

\section{METODE PENELITIAN}

Jenis penelitian yang dilakukan adalah penelitian hukum Yuridis Empiris yang bersifat tentang bagaimana Kekuatan akta notaris dalam menjamin hak keperdataan dilapangan yakni dengan mengumpulkan data yang terdapat di lapangan dan menghubungkan dengan Undang-undang terkait dengan hukum perdata.

\section{HASIL DAN PEMBAHASAN}

\section{A. Jaminan Akta Notaris Terhadap Hak Keperdataan.}

Didalam ilmu hukum terdapat beberapa macam hak diantaranya hak mutlak dan hak nisbi. Sebelumnya terlebih dahulu penulis jelaskan tentang pengertian hak. Menurut pendapat C.S.T Kansil dalam bukunya Pengantar Ilmu Hukum dan Tata Hukum Indonesia yang beliau kutip dari pendapat L.J. Van Apeldroon bahwa: 
"Hak ialah hukum yang dihubungkan dengan seorang manusia atau subjek hukum tertentu dan dengan demikian menjelma menjadi suatu kekuasaan dan suatu hak timbul apabila hukum mulai bergerak"

Dalam hukum seseorang yang mempunyai hak milik atas dari benda kepadanya diizinkan untuk menikmati hasil dari benda miliknya. Benda tersebut dapat dijual, digadaikan atau diperbuat apa saja asalkan tidak bertentangan dengan Undang-Undang. Yang dimaksud dengan hak mutlak ialah hak yang memberikan wewenang kepada seseorang untuk melakukan perbuatan, hak mana dapat dipertahankan terhadap siapapun juga, dan sebaliknya setiap orang juga harus menghormati hak tersebut.

Hak mutlak dapat dibagi dalam 3 (tiga) golongan:

a. Hak asasi manusia, misalnya hak seseorang untuk dengan bebas bergerak dan tinggal dalam suatu Negara.

b. Hak publik mutlak, misalnya hak negara untuk memungut pajak dari rakyatnya.

c. Hak keperdataan, misalnya hak marital (hak seorang suami untuk menguasai istrinya, hak kekuasaan orang tua, hak perwalian dan pengampunan dan sebagainya.

Sedangkan hak nisbi (relatife), ialah yang memberikan wewenang kepada seseorang tertentu atau beberapa orang tertentu untuk agar supaya seseorang atau beberapa orang lain tertentu memberikan sesuatu, melakukan sesuatu atau tidak melakukan sesuatu. "Hak relatife sebagian besar terdapat dalam hukum perikatan yang timbul bersangkutan".

Dari persetujuan jual beli terdapat hak relative seperti: hak penjual untuk menerima pembayaran dan kewajibannya untuk menyerahkan barang kepada pembeli, dan hak pembeli untuk menerima barang dan kewajibannya untuk melakukan pembayaran kepada penjual.

Dari uraian tentang hak tersebut, maka penulis akan menguraikan khusus tentang hak keperdataan dalam hak relative yang berasal dari persetujuanpersetujuan oleh para pihak. Dalam praktek hukum di masyarakat, antar pribadi dengan pribadi yang lain selalu melakukan perbuatan-perbuatan yang berhubungan dengan hukum, misalnya hutang piutang, jual beli, perkawinan, kerjasama dalam suatu usaha, menerima hak, melepaskan hak, menghibahkan, wasiat dan sebagainya.

Keseluruhan hal diatas dapat dituangkan ke dalam akta otentik yang dibuat oleh pejabat yang berwenang atas dasar ketentuan Undang-Undang dalam hal ini adalah Notaris. Hubungan perbuatan hukum yang dilakukan antar subjek hukum (badan hukum dan manusia) akan lebih terjamin dan berkekuatan hukum jika hal itu dibuat dan dituangkan oleh dan atau dihadapan Notaris. Meskipun perjanjian yang dibuat dibawah tangan juga dapat menjadi alat bukti dalam mempertahankan hak, akan tetapi hal itu dapat dibatalkan apabila terdapat bukti lain yang melemahkan atau 
membantah surat bukti yang dibuat di bawah tangan tersebut.

Pembahasan mengenai hak perdata yang termasuk dari bagian hak mutlak, penulis katakan dengan pembahasan tentang perbuatan, perjanjian dan penetapan. Ketiga hal ini merupakan bahan-bahan yang dapat diperbuat oleh Notaris ke dalam suatu akta otentik. Maksudnya adalah apabila antar individu atau pihak-pihak yang akan melakukan suatu perbuatan hukum dapat menjadi bukti bagi pihak-pihak yang tertera dalam akta otentik, sehingga mereka masingmasing memiliki dasar hukum untuk mempertahankan hak perdatanya.

Yang dimaksud perbuatan hukum adalah:

"Perbuatan dengan tujuan untuk pernyataan kemauan yang terkandung didalamnya, menciptakan suatu hak bagi seseorang atau merubah sesuatu hak yang telah ada atau mengakhirinya".

Demikian juga halnya dengan perjanjian, kesepakatan para pihak atau individu yang mengharap tentang perjanjian akan menjadi otentik dan bermakna pembuktian yang kuat apabila dinyatakan dalam suatu akta Notaris.

Sehingga berdasarkan pembahasan diatas dihubungkan dengan hak perdata subjek hukum (manusia dan badan hukum) untuk melakukan suatu perbuatan hukum, perjanjian dan penetapan atas apa yang mereka inginkan atau hendaki, merupakan tindakan yang dapat menjamin perbuatan, perjanjian dan penetapan tersebut jika dituangkan dalam akta otentik yang dibuat oleh Notaris, dan hak perdata mereka pun menjadi lebih terjamin oleh hukum dan tidak dapat di ganggu gugat oleh pihak lain sepanjang Undang-Undang tidak melarangnya.

\section{B. Kekuatan Akta Notaris dalam Pembuktian Perkara Perdata}

Kekuatan akta otentik maupun akta Notaris merupakan akibat langsung dari adanya tugas-tugas pejabat Notaris yanng diberikan oleh ketentuan Perundangundangan. Bahwa dalam hubungan hukum harus ada keterangan-keterangan otentik yang berguna sebagai alat pembuktian bagi pihak-pihak yang memberikan keterangan dan dituangkan ke dalam akta Notaris sehingga menjadi akta otentik.

Pemberian tugas kepada Notaris merupakan kepercayaan yang diberikan oleh Undang-Undang dan sekaligus pemberian pembuktian kepada akta-akta yang dibuat oleh Notaris. Notaris menuangkan dalam akta atas keterangan atau hasil dari apa yang disaksikan dalam melakukan jabatan Notaris sepanjang para pihak menginginkannya. Atau menuangkan secara otentik semua hal yang diterangkan oleh para pihak penghadap agar keterangan-keterangan tersebut dicantumkan dalam suatu akta dan tugas Notaris untuk membuat akta mengenai hal tersebut.

Pada akta Notaris terdapat 3 (tiga) kekuatan pembuktian yaitu:

1. Kekuatan pembuktian lahiriah

2. Kekuatan pembuktian formal

3. Kekuatan pembuktian material 
Yang dimaksud dengan kekuatan pembuktian lahiriah adalah kemampuan akta itu sendiri untuk membuktikan dirinya sebagai akta otentik, kekuatan pembuktian ini oleh pasal $1875 \mathrm{KUH}$ Perdata tidak dapat diberikan kepada akta yang dibawah tangan. Karena akta yang dibuat dibawah tangan baru berlaku sah, yakni sebagai yang benar-benar berasal dari orang terhadap siapa akta itu dipergunakan, apabila yang menandatanganinya mengakui kebenaran dari tanda tangannya itu apabila dengan cara yang sah menurut hukum dapat dianggap sebagai telah diakui oleh yang bersangkutan.

Berdasarkan pengertian kekuatan pembuktian akta otentik secara lahiriah dan tidak terdapatnya kekuatan pembuatan pada akta dibawah tangan, maka dapat diambil suatu penafsiran bahwa secara lahir akta otentik tersebut dapat membuktikan akan kebenaran bahwa akta yang dibuat oleh Notaris merupakan akta Otentik. Jadi akta itu sendiri yang membuktikan keotentikannya, sedangkan akta yang dibuat secara dibawah tangan tidak memiliki kekuaan pembuktian, tetapi kekuatan pembuktiannya hanya sebatas apabila orang yang menandatangani akta di bawah tangan itu mengakui secara sah menurut hukum dan diakui oleh yang bersangkutan.

Kekuatan pembuktian akta Notaris dalam perkara perdata dapat dimakukan dalam secara persidangan khususnya bagian pembuktian surat-surat. Dengan diajukannya akta Notaris yang berhubungan dengan silang sengketa yang sedang diproses, maka akan terlihat oleh para pihak bahwa sebelumnya benar ada peristiwa perjanjian yang disepakati, dan hal ini diketahui dari apa yang tertera dalam akta Notaris tersebut, misalnya para penghadap, tempat kedudukan, saksisaksi dan hal-hal yang telah diterangkan, diperjanjikan dan yang di tetapkan para pihak.

Menurut pendapat Sudikno Mertokusumo bahwa:

"Kekuatan pembuktian formal didasarkan atas benar tidaknya ada pernyataan oleh yang bertanda tangan dibawah akta itu. Kekuatan pembuktian formil ini memberi kepastian tentang peristiwa bahwa pejabat dan para pihak menyatakan dan melakukan apa yang dibuat dalam akta, sedangkan kekuatan pembuktian materil ini memberikan kepastian tentang materi suatu akta, memberi kepastian tentang peristiwa bahwa pejabat atau para pihak menyatakan dan melakukan seperti yang dimuat dalam akta"1

Selanjutnya penulis mencoba membahas kekuatan pembuktian akta otentik dengan melihat pada apa yang berlaku dalam hukum acara perdata. Sebuah azas yang mengatakan "akta publika probant sese ipsa" yang maksudnya adalah suatu akta yang lahirnya tampak sebagai akta otentik serta memenuhi syarat-syarat yang telah ditentukan, maka akta itu berlaku atau dapat dianggap sebagai akta otentik, sampai terbukti sebaliknya. Hal ini berarti bahwa tanda tangan pejabat dianggap

Sudikno Mertokusumo, Op.Cit, Hlm. 123 
sebagai aslinya, sampai ada pembuktian sebaliknya.

Beban pembuktiannya terletak pada siapa yang mempersoalkan otentik tidaknya. Beban pembuktian ini terikat pada ketentuan seperti yang diatur dalam pasal 138 HIR (pasal 164 Rbg, $148 \mathrm{Rv}$ ). Kekuatan pembuktian lahir ini berlaku bagi kepentingan atau keuntungan dan terhadap setiap orang dan tidak terbatas pada para pihak saja. Sebagai alat bukti, maka akta otentik ini keistimewaannya terletak pada kekuatan pembuktian lahir.

Dalam kekuatan pembuktian formil akta otentik, berari membuktikan kebenaran dari apa yang dilihat, dengan dan dilakukan pejabat. Ini adalah pembuktian tentang kebenaran dari pada keterangan pejabat sepanjang mengenai apa yang dilakukan dan dilihatnya. Dalam hal ini yang telah pasti ialah tentang tanggal dan tempat akta dibuat serta keaslian tanda tangan.

Kekuatan pembuktian materil akta otentik tidak lain hanya untuk membuktikan kebenaran apa yang dilihat dan dilakukan oleh Notaris. Apabila Notaris mendengar keterangan pihak yang bersangkutan, maka itu hanyalah berarti bahwa telah pasti pihak yang bersangkutan menerangkan demikian terlepas dari pada kebenaran isi keterangan tersebut. Semua akta otentik mempunyai kekuatan pembuktian materil ini diserahkan kepada pertimbangan hakim.

Kekuatan pembuktian akta Notaris (otentik), menurut pasal 165 HIR dalam pasal $285 \mathrm{Rbg}$ bahwa otentik sebagai akta partai, dibuat oleh atau dihadapan pejabat umum (Notaris) mempunyai nilai kekuatan pembuktian:

1 Sebagai alat pembuktian yang mempunyai kekuatan pembuktian yang sempurna (volledige bewijskracht) dan mempunyai kekuatan pembuktian yang mengikat (bindende bewijskracht):

a. Sempurna dan mengikat sebagai bukti terhadap pihak-pihak yang membuat akta.

b. Sempurna dan mengikat kepada ahli waris kedua belah pihak

c. Dan juga kepada setiap orang yang mendapat hak dari pada akta tersebut

2 Dan juga sebagai pembuktian yang sempurna tentang segala apa yang disebut dalam akta:

a. Baik mengenai isi materi pokok soal yang tertuang didalamnya

b. Demikian juga tentang yang berupa pemberitahuan belaka yang ada hubungannya dengan pokok persoalan

3 Merupakan kekuatan sebagai keterangan resmi dari seorang pejabat yang membuang akta tersebut tentang:

a. Apa yang dialami si pejabat tadi pada waktu pertumbuhan akta, baik tentang kebenaran pihakpihak yang menghadap kepadanya, serta apa yang diucapkan pihak-pihak yang menghadap itu.

b. Dianggap benar oleh hakim dan terhadap semua orang tentang 
tanda tangan dan tanggal pembuatan surat akta otentik tadi

Sifat kesempurnaan akta Notaris (otentik) dapat dijelaskan sebagai berikut:

1. a) Sifat kesempurnaan itu tidak merupakan alat pembuktian yang mempunyai kekuatan yang memaksa (dwingende bewijskracht. b) Sifatnya juga tidak merupakan alat pembuktian yang mempunyai kekuatan yang menentukan (bersissende bewijskracht).

2. Akan tetapi sifat sempurnanya itu tidak memerlukan pengakuan dari pihak-pihak yang bersangkutan supaya akta itu mempunyai kekuatan yang sempurna. Sebab itu jika pihak lawan hendak melumpuhkan akta otentik mengenai kepalsuan isi dan tanda tangan, maka untuk itu orang tersebut harus melakukan dengan tuduhan dakwaan pemalsuan surat kepada kejaksaan.

3. Kesempurnaan akta otentik selamanya dianggap benar sampai ada bukti lawan yang dapat melumpuhkannya. Pelumpuhan dengan bukti lawan itu dipikulkan kepada pihak yang melakukan perlawanan tadi, sehingga misalnya: kalaupun seseorang itu mempunyai akta tetapi dapat dilumpuhkan pihak lawan, maka surat akta tadi dianggap tidak ada.

\section{Peranan dan Fungsi Akta Notaris Dalam Hubungan Perdata Subjek Hukum}

Membicarakan peran dan fungsi tidak terlepas dari kegunaan dan manfaat dari akta Notaris di dalam masyarakat. Hubungan anggota masyarakat antara satu dengan yang lain, baik antar subejk hukum (manusia dan badan hukum ) dengan yang lainnya. Dalam hal ini dilihat khusus hubungan subjek hukum secara perdata, bukan secara publik yang bersifat kenegaraan atau umum.

Kepentingan hukum subjek hukum (manusia dan badan hukum) harus dijamin atas dasar ketentuan keperdataan. Karena badan hukum ataupun manusia selalu mengikatkan diri dalam suatu persetujuan atau perjanjian. Misalnya dalam dunia perdagangan selalu terjadi hutang piutang, jual beli dan sebagainya. Contoh yang sering terjadi adalah A berhutang uang pada $\mathrm{B}$ dengan memakai jaminan, untuk perikatan ini mereka sepakat menuangkan hutang piutang tersebut ke dalam akta Notaris agar menjadi otentik. Demikian juga dengan jual beli, dapat dimintakan kepada Notaris untuk dibuat akta jual beli tersebut dan sebagainya.

Contoh-contoh di atas dapat dikatakan adanya hubungan perdata antar subjek hukum (manusia dan badan hukum) secara perikatan dan dituangkan ke dalam akta Notaris, sehingga menjadi dasar pembuktian dari pada yang telah para pihak perbuat, perjanjian dan ditetapkan atas kepentingan masingmasing. 
Hubungan-hubungan perdata antar subjek hukum yang dituangkan ke dalam akta Notaris (otentik) inilah yang penulis maksudkan akan berperan dan berfungsi di masyarakat. Hal ini menunjukkan dinamika suatu masyarakat dalam melakukan hubungan yang satu dengan yang lain. Karena akta Notaris sebagai alat bukti yang sah dan berkekuatan hukum, maka sudah selayaknya subjek hukum (orang dan badan hukum) mempergunakannya untuk menjamin hak perdata mereka, setelah terjadinya suatu perjanjian tertentu antara subjek hukum.

\section{Analisa kasus}

Kasus Posisi

Pengadilan Negeri Bukittinggi telah memeriksa dan mengadili perkara perdata Nomor 13/PDT/G/1989/PN-BKT antara H.Muchtar sebagai Penggugat, lawan Armen Effendi bakar dan Havid Dt. Manindih sebagai tergugat.

Pada gugatan tersebut, penggugat menggunakan surat bukti perjanjian pemborongan yang dilegalisir oleh Notaris Pengganti Burahim Esde tanggal 28 Juli 1986 dibawah nomor 16217/1986 dan perobahannya yang juga dilegalalisir oleh Notaris Pengganti Buharim Esde pada tanggal 29 Juli 1986 di bawah nomor 16219/1986 (PI) dan surat bukti akte Notaris nomor 20 tanggal 5 November 1986 yang dibuat di hadapan Notaris Ny. Julinar Idris, SH (PII)

Terhadap surat bukti tersebut, salah satu petitum gugatan Penggugat (Petitum No.2), Meminta kepada Majelis Hakim mensyahkan surat bukti yang dilegalisir di hadapan Notaris Pengganti Burahim Esde, SH (PI).

Adapun gugatan yang diajukan Penggugat sebagai berikut:

Bahwa antara Penggugat dan Tergugat pada tanggal 28 Juli 1986 telah mengadakan perjanjian pemborongan toko bertingkat yang terletak di jalan syech Bantam Kotamadya Bukittinggi.

Bahwa jumlah harga borongan tersebut adalah sebesar Rp. 192.000.000,(Seratus sembilan puluh dua juta rupiah) untuk 10 (sepuluh) buah toko bertingkat.

Untuk membiayai pembangunan toko tersebut mendapat pinjaman dari bank yang diusahakan oleh Tergugat I. Pelaksanaan pekerjaannya sampai selesai 100\% selama 240 hari kalender, terhitung sejak tanggal I menerima pembayaran uang muka dan surat jaminan bank (Bank Garansi) sebagai jaminan pembayaran dari Penggugat sebagai Pihak Pertama yang memborongkan pekerjaan.

Atas usaha tergugat I, Penggugat mendapat kredit dari PT. Bank Nasional Bukittinggi dengan surat utang Nomor 20 yang dibuat di hadapat Notaris Ny. Julinar Idris, SH pada tanggal 6 November 1986, adapun kredit yang Penggugat peroleh sebesar Rp. 67.500.000,- ( enam puluh tujuh ribu lima ratus ribu rupiah) untuk pembangunan 3 buah petak toko bertingkat.

Sebagai jaminan utang Penggugat kepada Bank nasional, Penggugat telah menyerahkan secara P.E.O ( fiduciare Eigendom Overdracht) ketiga toko 
tersebut yaitu toko yang terletak di jalan syech bantam No. 16B, 16C dan 20.

Terhadap perjanjian tersebut Penggugat telah memenuhi kewajiban menyerahkan toko kepada Tergugat yaitu toko No. 16B dan 16C, sedangkan toko No. 20 tetap dikuasai oleh tergugat walau perjanjian telah habis masa kontraknya.

Tiba-tiba pada tanggal 24 Juli 1987 tanpa diduga oleh Penggugat toko No 20 oleh Juru Sita Pengganti Pengadilan Negeri Bukittinggi melakukan pengosongan terhadap toko No. 20 dan menyerahkan toko No. 20 tersebut kepada tergugat II, dasar penyerahan adalah:

Berdasarkan putusan Pengadilan Negeri Bukittinggi dalam perkara perdata No. 69/B.Q/1981/PN-BKT dan keputusan pengadilan Tinggi DBP No. 25/B/Q/1983 PT PDG dan keputusan Mahkamah Agung RI reg No. 75/K/PDT. 1984.

Terhadap putusan tersebut Penggugat mengajukan bantahan akan tetapi Juru Sita Pengadilan negeri Bukittinggi tetap melaksanakan eksekusinya.

Atas tindakan pengadilan Negeri Bukittinggi Penggugat mengadukan permaslahannya kepada bapak Ketua mahkamah Agung RI di Jakarta dan bapak Ketua Pengadilan Tinggi di Padang kemudian pada tanggal 27 November 1987 Juru Sita Pengadilan Negeri Bukittinggi mencabut pembatalan Berita Acara Pengosongan/penyerahan yang dilaksanakan oleh Juru Sita Pengganti Pengadilan Negeri Bukittinggi tertanggal 28 Januari 1987 terhadap toko syech Bantam No. 20 dan terhadap toko No. 20 tersebut statusnya keadaan sebelum adanya perkara.

Atas perintah mahkamah Agung RI terhadap pencabutan/pembatalan berita Acara pengosongan/penyerahan yang dilaksanakan oleh Juru Sita Pengadilan negeri Bukittinggi, Tergugat II tidak bersedia keluar/mengosongkan toko bahagian bawah yang dikuasai dengan alasan ia tidak serta dalam perjanjian pemborongan tanggal 29 Juli 1986.

Akibat tidak diserahkannya toko tersebut tergugat I selaku pemborong tidak dapat membongkar toko yang lama untuk dibangun toko yang baru dan pada tanggal 29 Juli 1986 tergugat II telah menyetujui serta menyerahkan kepada tergugat ! dengan surat pernyataan tertanggal 29 Juli 1986 yang antara lain isinya sebagai berikut :

a. Tergugat II menyetujui perjanjian yang telah dibuat antara Penggugat dan tergugat I tanggal 28 Juli 1986.

b. Bahwa dengan persetujuan itu, maka dengan sendirinya Tergugat II telah termasuk selaku pihak pertama dari surat perjanjian tanggal 28 Juli 1986 tersebut di atas.

Walaupun telah adanya surat perjanjian tersebut dan instruksi dari Mahkamah Agung RI agar eksekusi yang telah dilaksanakan di batalkan, namun kenyataan toko No. 20 tersebut tetap dikuasai oleh Penggugat II.

Dengan tidak diserahkannya toko oleh tergugat I maupun tergugat II kepada 
Penggugat (toko No. 20) sesuai dengan perjanjian kontrak bangunan tanggal 28 Juli 1986 dan perubahannya tanggal 29 Juli 1986 adalah merupakan suatu wanprestasi sehingga dapat menimbulkan kerugian suatu wanprestasi sehingga dapat menimbulkan kerugian pada Penggugat sebesar Rp. 10.000.000,- sejak bulan Juni 1987 sampai bulan November 1989 ditambah Rp. 4.000.000,- setiap tahunnya sampai Tergugat - tergugat menyerahkan toko bertingkat jalan syech Bantam No. 20 Bukittingi kepada Penggugat, maka Penggugat dalam salah satu petitum gugatannya meminta kepada Majelis Hakim menyatakan syah kontak perjanjian pemborongan yang dilegalisir oleh Notaris Pengganti Burahim Esde pada tanggal 28 Juli 1986 di bawah No. 16217/1986 dan perobahannya yang juga dilegalisird oleh Notaris pengganti Buharahim Esde pada tanggal 29 Juli 1986 di bawah No. 16219/1986 (petitum) No. 2.

Terhadap tergugat tersebut telah diputuskan oleh Pengadilan Negeri Bukittinggi pada tanggtal 29 Oktober 1990 yang amarnya berbunyi sebagai berikut:

\section{DALAM KOMPENSI:}

\section{DALAM EKSEPSI:}

- Menolak eksepsi Tergugat I

- Menerima eksepsi tergugat II sebagian

- Menyatakan gugatan terhadap Penggugat II tidak dapat diterima (nebis in indem)

\section{DALAM POKOK PERKARA}

- Mengabulkan gugatan Penggugat masuk sebagian;
- Menyatakan perjanjian pemborongan pembangunan toko, kontrak No 16217.1986 tertanggal 28 Juli 1986 dan perobahannya tertanggal 29 Juli 1986 adalah sah.

- Menghukum tergugat I untuk menyerahkan 3 petak toko jalan syech Bantam No. 16B, 16 C dan No. 20 Bukittinggi kepada Penggugat sejak bulan Juli 1987;

- Menyatakan bahwa perbuatan tergugat I yang tidak mau menyerahkan toko Jalan Syech Bantam No. 20 Bukittinggi kepada penggugat adalah merupakan perbuatan wanprestasi;

- Menghukum Tergugat I untuk menerima uang perlunasan kontrak perjanjian pemborongan dari Penggugat;

- Menolak gugatan selebihnya. DALAM REKONPENSI

- Menyatakan gugatan rekonpensi penggugatan rekonpensi/Tergugat I konpensi di tolak seluruhnya.

DALAM KONPENSI DAN REKONPENSI

- Membebankan biaya perkara kepada Tergugat I konpensi/Penggugat rekonpensi biaya perkara sebesar Rp. 114.500,- (seratus empat belas ribu lima ratus rupiah)

Terhadap putusan Pengadilan Negeri Bukittinggi Tergugat-tergugat mengajukan banding, tertanggal 8 November 1990 dan Pengadilan Tinggi Padang telah menjatuhkan putusan tertanggal 20 Agustus 1991.

Yang amarnya berbunyi sebagai berikut:

Pengadilan Tinggi:

- Menerima permohonan akan pemeriksaan dalam peradilan tingkat banding yang diajukan 
oleh kedua belah pihak dalam perkara ini.

- Menguatkan putusan Pengadilan negeri Bukittinggi tanggal 29 Oktober Perdata No. 13/PDT.G/1989/PN.BKT, dalam perkara antara kedua belah pihak yang dimohonkan pemeriksaan dalam tingkat banding;

- Menghukum para tergugatTerbanding/Pembanding untuk membayar biaya perkara dalam tingkat banding yang sampai hari ini berjumlah Rp. 10.000; (sepuluh ribu rupiah)

Atas putusan - putusan Pengadilan Tinggi padang tersebut tergugat menngajukan kasasi ke Mahkamah Agung tertanggal 10 Oktober 1991 dan 5 November 1991 dan oleh Mahkamah Agung dijatuhkan Putusan pada tanggal 28 september 1993 yang amarnya berbunyi sebagai berikut:

Mahkamah Agung:

Menyatakan, bahwa permohonan kasasi dari Pemohon kasasi II : $\underline{\text { Havid DT. }}$ Manindih tersebut tidak dapat menerima;

Menolak permohonan kasasi dari pemohon kasasi I ARMEN EFENDI BAKAR DAN Permohon kasasi III : $\underline{\mathrm{H}}$. MUCHTAR TERSEBUT:

Menghukum Pemohon kasasi I,II dan III untuk membayar biaya perkara dalam tingkat kasasi ini ditetapkan masing masing Rp. 20.00,- (dua puluh ribu rupiah).

Dari putusan Pengadilan Negeri, Pengadilan Tinggi, Mahkamah Agung dapat diambil catatan terhadap surat bukti yang menggunakan akta Notaris sebagai berikut:

Surat bukti PI yang merupakan perjanjian pemborongan yang dilegalisir oleh Notaris Pengganti Burahim Esde dinyatakan sah oleh putusan Pengadilan Negeri Bukittinggi yang dikuatkan Pengadilan Tinggi dan Mahkamah Agung.

Adapun petitum berupa hukum Pengadilan Negeri Bukittinggi karena surat bukti P I dikuatkan surat bukti T I. IV dan T II. IV yang merupakan perjanjian pemborongan antara Penggugat dengan Tergugat (sama dengan surat dengan bukti mPenggugat I) di samping itu Tergugat tersebut, sedangkan terhadap surat bukti P II merupakan surat bukti pendukung untuk menguatkan surat bukti PI maka terhadap surat PII ini yang juga merupakan akta Notaris keabsahannya/kekuatannya tidak dipermasalahkan dalam putusan Pengadilan Negeri maupun Pengadilan Tinggi dan Mahkamah Agung.

\section{SIMPULAN DAN SARAN}

Setelah membahas permasalahanpermasalahan yang ada dalam penelitian ini, maka penulis mengambil kesimpulan sebagai berikut:

1 Peranan dan fungsi akta Notaris terhadap hubungan hukum antar subjek hukum (orang dan badan hukum) adalah untuk mensyahkan secara formal isi (materi) yang diperjanjikan atas dasar kepentingan pihak - pihak, sehingga memiliki 
fungsi mempertegas hubungan hukum yang berkaitan dengan hak, kewajiban dan tanggung jawab para pihak yang tertera dalam suatu akta otentik (Notaris).

2 Kekuatan hukum akta Notaris apabila dipergunakan sebagai alat pembuktian dalam perkara perdata adalah sebagai bukti yang sempurna ataupun formal untuk mendukung keterangan saksi, sepanjang para pihak yang tertera dalam suatu akta notaris tersebut sadar dan tanpa paksaan pada saat pembuatan akta dan tidak ada pembatalan oleh para pihak, maka Notaris tersebut menjadi alat bukti yang sempurna atau formal, sehingga tidak dapat dikesampingkan pada forum peradilan perkara perdata.

3 Tanggung jawab seorang Notaris atas kerugian yang diderita oleh kliennya apabila karena kelalaiannya seorang klien dirugikan maka Notaris yang bersangkutan karena kelalaiannya dapat dituntut ganti rugi seperti dalam hal batalnya sesuatu akta dapat menimbulkan kerugian pada orangorang yang bersangkutan, dan itu dapat memberikan peluang kepada mereka itu untuk menuntuk ganti rugi kepada Notaris yang bersangkutan karena kelalaiannya, bukan karena perbuatan melawan hukum (onrech matige daad). Dalam hal ini Notaris, karena ketentuan yang tersebut dalam peraturan jabatan Notaris sendiri mempunyai pertanggung jawaban keperdataan (civielrechttelijk verantwoordelijkheid).
4 Peranan Notaris dalam pembuatan akta baik di dalam teori hukum maupun praktek adalah Notaris juga ditugaskan untuk melakukan pendaftaran dan mensyahkan suratsurat/akta-akta yang dibuat di bawah tangan. Selain itu Notaris berperan juga memberikan nasehat hukum dan menjelaskan mengenai undangundang kepada pihak-pihak yang bersangkutan dan datang menghadap kepada Notaris untuk membuat suatu perjanjian tertentu dengan pihak lain. Secara praktek tindakan harus menjadi penasehat para kliennya secara tidak mutlak.

Adapun yang menjadi saran-saran ataupun usul dari penulis tentang pembahasan penelitian ini, khususnya yang berkaitan dengan akta otentik (Notaris) adalah sebagai berikut:

1. Akta Notaris (otentik) sebagai alat pembuktian yang sempurna harus tetap menjadi pedoman dasar mengadili oleh para hakim dan rujukan bagi bagi para pihak dalam menyelesaikan silang sengketa perdata. Karena apa yang tertera di dalam akta otentik (Notaris) tersebut merupakan catatan resmi tentang perbuatan, perjanjian dan ketetapan yang diajukan para pihak, kemudian hal itu disahkan, disaksikan dihadapan pejabat Notaris atas dasar keinginan mereka.

2. Hendaknya para catur wangsa (hakim, jaksa, pengacara, polisi dan Notaris) benar-benar meneliti keabsahan hukum suatu akta otentik 
(Notaris) dalam mempergunakan akta Notaris yang ada pada suatu silang sengketa.

3. Sebaiknya akta Notaris dalam pembuatannya harus memperinci secara jelas segala peristiwa hukum yang terjadi sehingga tidak menimbulkan kekaburan bagi akta tersebut sehingga hakim mengalami kesulitan dalam menilai isi akta tersebut.

\section{UCAPAN TERIMAKASIH}

Puji dan Syukur penulis ucapkan ke hadirat Allah SWT yang telah memberikan Rahmat dan Karunia-Nya, sehingga akhirnya penulis dapat menyelesaikan penulisan karya ilmiah ini yang berjudul: "KEKUATAN AKTA NOTARIS DALAM MENJAMIN HAK KEPERDATAAN"

Penulis menyadari bahwa tanpa bantuan dan dorongan dari berbagai pihak tidak mungkin karya ilmiah ini dapat diselesaikan. Oleh karena itu pada kesempatan ini dengan segala kerendahan hati, penulis ingin mengucapkan terimakasih dan penghargaan yang sebesar-besarnya kepada:

1. Bapak Dr. Eviandi Ibrahim S.H., M.Hum selaku Ketua Sekolah Tinggi Ilmu Hukum Putri Maharaja Payakumbuh

2. Seluruh rekan-rekan Dosen Sekolah Tinggi Ilmu Hukum Putri Maharaja yang tidak dapat penulis sebutkan satu-persatu.

\section{DAFTAR PUSTAKA}

Ardiwilaga, Roestandi, 1962, "Hukum Agraria Indonesia Dalam Teori dan Praktek”, NV, Mas Baru, Bandung.

Abdulrrahman, 1978, “Kedudukan Hukum Adat Dalam Rangka Pembangunan", Cet. ke I, Alumni Bandung.

Bahri, Syamsul, 1981, "Pelestarian Tanah Ulayat Dengan Model Suku”, Unand Press.

1982, "Pendaftaran Tanah Ulayat, Transaksi dan Hak Pertanggungan Atas Tanah", Unand Press.

1987, "Hukum Agraria Indonesia Selayang Pandang”, Unand Press.

1987, "Beberapa Aspek Hukum Adat Yang Berpengaruh Terhadap Pendaftaran Tanah", Disertasi, KPK, UGM-USU, Medan.

Boerhan, Boerma dkk, 1983, "Tanah Ulayat Dalam Pembangunan”, Unand Press.

Darus, Mariam, 1989, "Perjanjian Kredit Bank", Cet. ke empat, Alumni Bandung.

1991, "Bab-Bab Tentang Kreditetverband Gadai dan fiducia”, Citra Aditya Bandung, Bandung.

Effendi Syofyan, 1984, "Hukum Agraria di Indonesia, Kumpulan Lengkap Undang-Undang dan Peraturan", Jilid 1-9, Ghalia Indonesia.

Harsono, Boedi, 1970, "UUPA Sejarah Penyusunan Isi dan Pelaksanaannya", Jilid ke dua, Jembatan Jakarta.

, 1976, “BPHN, Seminar

Hukum Adat dan Pembinaan 
Rahmawati Boty: Kekuatan Akta Notaris dalam Menjamin Hak Keperdataan

Hukum Nasional", Cet. ke satu, Bina Cipta Bandung.

1988, "Hukum Agraria

Indonesia Himpunan Peraturan

Hukum Tanah", Cet ke delapan, Jembatan.
Hakimi, Idrus, 1988, "Adat Alam Minangkabau”, CV. Rosda, Bandung.

Kode Etik..Notaris. 